\title{
The Effect of Project Management Performance With the Roles of Project Risk Management: Evidence From ICT Projects in Public Healthcare Sectors in Jordan
}

Baker Ibrahim Alkhlaifat, Abdul Aziz Abdullah, Zaydoon Dhafi Al-Khamaiseh

To Link this Article: http://dx.doi.org/10.6007/IJARBSS/v11-i3/8869 DOI:10.6007/IJARBSS/v11-i3/8869

Received: 21 January 2021, Revised: 23 February 2021, Accepted: 10 March 2021

Published Online: 26 March 2021

In-Text Citation: (Alkhlaifat et al., 2021)

To Cite this Article: Alkhlaifat, B. I., Abdullah, A. A., \& Al-Khamaiseh, Z. D. (2021). The Effect of Project Management Performance With the Roles of Project Risk Management: Evidence From ICT Projects in Public Healthcare Sectors in Jordan. International Journal of Academic Research in Business and Social Sciences, 11(3), 1278-1304.

\section{Copyright: (c) 2021 The Author(s)}

Published by Human Resource Management Academic Research Society (www.hrmars.com)

This article is published under the Creative Commons Attribution (CC BY 4.0) license. Anyone may reproduce, distribute, translate and create derivative works of this article (for both commercial and non-commercial purposes), subject to full attribution to the original publication and authors. The full terms of this license may be seen at: http://creativecommons.org/licences/by/4.0/legalcode

Vol. 11, No. 3, 2021, Pg. 1278 - 1304

Full Terms \& Conditions of access and use can be found at http://hrmars.com/index.php/pages/detail/publication-ethics 


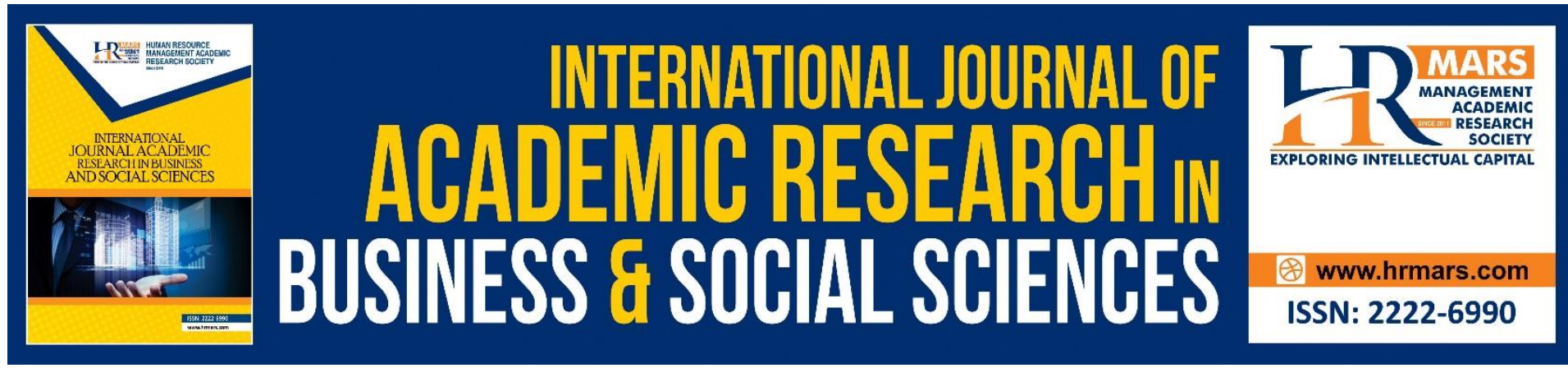

\title{
The Effect of Project Management Performance With the Roles of Project Risk Management: Evidence From ICT Projects in Public Healthcare Sectors in Jordan
}

\author{
Baker Ibrahim Alkhlaifat, Abdul Aziz Abdullah \\ Faculty of Business and Management, Universiti Sultan Zainal Abidin, Kuala Terengganu \\ Malaysia \\ Email: bakerkhlifat@hotmail.com, abdulazizum@gmail.com
}

\author{
Zaydoon Dhafi Al-Khamaiseh \\ Ajyal Al Asr Institute \\ Email: Zdtk70@gmail.com
}

\begin{abstract}
Project management has grown rapidly in the last few decades in numerous developing countries, and is now commonly used in various fields: construction, agriculture, manufacturing, IT, telecommunications, education etc. The high value of effective project management was determined by the high occurrence of multi-sector projects. This study explored the mediatory impact of Project Risk Management (PRM) in the relationship among the ICT projects in the Jordanian health care field between Project Management Efficiency (PMP) and Project Progress (PS). The study targets 457 ICT workers in the Jordanian Health Minister (MOH). In addition, 208 ICT workers in the Ministry of Health of Jordan are sampled in this report. Likewise, to prevent an answer error, the sample is up to 400.300 valid responses were obtained from the questionnaire administered (representing 75.0 percent response rate). In addition, the analysis evaluated the research hypothesis using the Structural Equation Model (SEM). The findings showed the optimistic and statistically important impact of project management on project performance. Likewise, there were statistically significant positive effects on project risk management as a result of project management success. In addition, project risk management has major positive impacts on the performance of the project. The results indicate, in addition, that the relationship between project management efficiency and project success is mediated in part by project risk management. This study recommended that the greater implementation of the factors of project management contribute to greater project performance, which encourages clients (patients) in the Jordanian healthcare sector to remain in the ICT projects and recommend the industry to others. ICT ventures in Jordan's healthcare sector should therefore concentrate on setting a high level of satisfaction for customers to create positive customer contacts.
\end{abstract}


Keywords: ICT Projects, Health Sector, Project Success, Structural Equation Model (SEM), Risk Management

\section{Introduction}

In recent decades there have been fruitful debates and analysis on project performance studies (Cooke-Davies, 2002; Judgev \& Müller, 2005; Müller \& Turner, 2007; Magassouba \& Alkhlaifat, 2018).). PM phase involves planning, initiation, observation, execution, regulation and conclusion of which empower the project's typically richest resources (Watt, 2014). These stages of project management success have completed the project life cycle step by step in order to protect the stakeholders and the components as defined in the project (Humaidi \& Asarani, 2012). The world undergoes an important transition, such as the dramatic advancement of technology. Customers often have to adapt quickly and it is difficult to obtain their satisfaction. In the health sector, demand has increased for infrastructure facilities, internet services and IT and technology programmes (Fraser, Castrucci \& Harper, 2017; Alkhlaifat,Tambi \& Mansour, 2017). The project is the way for organisational growth according to Raheem, Olateju \& Hammed, (2012). One of the project initiatives that the company is searching for is ICT projects. ICT projects. In developed and developing countries like Jordan ICT therefore has an important impact on companies and promotes productivity and economic growth (Papaioannou et al., 2004, Manochehri, Al-Esmail \& Ashrafi, 2012).

Project management has developed rapidly in many developing countries over the last decades; it is currently widely used in various areas such as building, agriculture, development, IT, telecommunications, educational activities, etc (Muriithi, Horner \& Pemberton, 2016; Alkhlaifat \& Alshaweesh,2017). The high value of effective project management was determined by the high occurrence of multi-sector projects. The greatest challenge for project managers remains the correct management of the project at the right time (technical dimension and human). The relation between the successful project and the project output is an unfair subject of project management (Mathiaszyk, Volkmann, \& Read, 2019). The issue of project success is therefore still relevant in developing countries such as Jordan. Based on their commitment to the process of transition or implementation of policies, consumers have an animated role in the failure or success of IT systems. Residents and staff are largely responsible for human factors associated with ICT programmes. ICT programmes will also aim to strengthen people-government communication and to enhance cooperation on this link. Such cooperation involves collaboration and communication between individuals, companies and public bodies (Kraft \& Furlong, 2019).

There have been many research findings that the effectiveness of PM is greatly affected by Project Management (PMP) (Cooke-Davies, 2004; Shenhar \& Dvir, 2007; Dine et al., 2011; de Carvalho et al., 2015; Joslin \& Müller, 2015). Existing studies have also shown, however, that Project Management methodology does not completely justify improvements to project performance (Mir and Pennington, 2014; Joslin\&Müller, 2015). That is proof of the fact that there are multiple ways to assess project performance and that direct comparison of the scale of the project's success is not always done (Davis 2016). Regarding project risk management, it has a positive impact on the timely implementation of projects (McGrew \& Bilotta, 2000; Channar et al., 2015), leading to a realistic evaluation of the assets needed to accomplish a particular assignment (Rabechini Junior and Monteiro de Carvalho, 2013 and Cabral, 2017). (Altahtooh \& Emsley, 2015). Bannerman (2015) also states that frequent and constant demands by project managers for risk management procedures in many projects make a positive contribution over time to risk management effectiveness in projects. 
Jordan is a common economic development context with rising project failures and delays (Al-Moumani, 2000; Odeh \& Battayneh, 2002; Albogamy et al., 2013; Sweis et al., 2008, 2014; Abu-Shanab et al., 2016). Assbeihat, 2016 recognised the delay causes as designers, owners shift, weather, different site conditions and delaying material delivery, economic conditions and rises in quantity. The critical factors that have hindered projects in Jordan have been Al-Moumani (2000) described owner participation, poor entrepreneurial skills, funding and payments, labour productivity, slow decision making. The external factors behind delayed project management performance, including conditions, modification of government regulations, budgetary complexity, owner change orders, lack of coordination and plans for contractor staff, untrained personnel and skills and practical experts have been highlighted by Sweis et al. (2008).

Moreover, some studies in Jordan focused on building projects (Albogamy et al., 2013; Sweis et al., 2014; Assbeihat, 2016). Scientists like Abu-Shanab et al. (2013:216) and Sweis (2015) focused nonetheless on IT and IS. Sweise (2015) classifies into two sections, namely managerial and technical issues, factors associated with the failure of IS projects. AbuShanab\&Al-Saggar, 2013, concluded that insufficient planning, lack of goals and objectives, changing project objectives during project execution are the most important factors that affect IT project efficiency in Jordan and that no relationship exists between project need and organisational culture. Risk management has been an important part of the method of project management. Assessing and taking measures against the level of risk reduction is therefore one of the most challenging tasks facing Jordan's PMs. In addition, the difficulty of the ICT project has helped reduce the likelihood of projects in ICT projects (Al-Shibly et al., 2013; AlKhamaiseh, Halim, Mohamad, Afthanorhan, AL Qahtani \& Alkhlaifat,2019). The aim of this paper is therefore to evaluate the mediation impact on the ties between PPP and PS of ICT projects in the Jordanian healthcare sector, of the Project Risk Management (PRM) relationship.

\section{Literature Review and Development of Hypothesis}

The top executive needs to think innovatively how the project risk management can be used to mediate the relationship between PM performance and project success(PS) effectively in order to build advantages derived from ICT projects in the health sector, and achieve success.

\section{Project Management Performance and Project Success}

Various studies have studied the effect and the effectiveness of PMPs, such as (Mir \& Pinningto, 2014; Aftab et al., 2016; Fernando, Walters, Ismail, Seo\&Kaimasu, 2018). The ties between individual PMP and individual project success components have already been discussed by Mir and Pinnington, (2014) as well as the relation between PMP and project success. As a research tool, a questionnaire was developed. It has been distributed in UAE project-based organisations, among various PM experts. The experiment's results show that the PMP and its significant project success variables have a positive impact and relation where the individual KPIs are the most important individual variable for any project's success. The robust PMP could also increase the likelihood of project completion and increase the potential. The project management variable is also an important part of achieving project performance, but the results indicate that PMP has comparatively little effect and impact on project productivity. This study met obstacles that do not fully identify the relationship between PMP and the progress of the project. Further experimental research is required to explore the link. In addition, the participants in the inquiry were limited to simplifying the 
guidelines, and there were no considerations of organisational culture as a success factor. Project performance view that particular wishes for a given part are fulfilled, regardless whether the owner, organiser, initiator, temporary worker or administrator is satisfied. Therefore, the outcomes of the project are much better than anything predicted or sometimes observed: the scale of the costs, the timeframe, efficiency, safety and the satisfaction of the parts (Naeem, Khanzada, Mubashir\&Sohail, 2018). If a project meets the clear executive decision or conceivably mission to be carried out, and the result of the assignment between entries into the parent's association is unusual, enter people at the venture and fundamental (Idoro,2012; Magassouba, Tambi, Alkhlaifat, Abdullah, 2019).

The success part of the project is how many goals and wishes are fulfilled. They also included the possibility of entering unique money linked, enlightening and social objectives (Sanvido et al., 1992). Many exact research findings indicate that project progress is positive (Fabricius\&Büttgen, 2015). The outcomes of these projects are positive. The PMP is also explicit about the purpose, objectives and strategies necessary for the project to reach a productive end through its cycle of life when the element, management or process of the project takes its legitimate place in the execution of project proprietor procedures (Cleland \& Ireland, 2006). Various experts have discussed broader ways to predict the progress of this initiative. PMPs for the project under review may have a substantial influence on the project progress (Zwikael et al., 2014) (Rahrovani, Chan, \&Pinsonneault, 2014). The literature on project management argues that PMP is optimistic and that the success of the project is based in part on the estimation of the value of project management (Bride, 2008; Munns and Bjeirmi, 1996) and Munns and Bjeirmi (1996). It has been argued from the above dialogue, that the success of the project and PMP are especially sought between related ideas and their positive relation. The different elements of the PMP indicators and project performance were decided by Aftab, Sarwar, Sarwar \& Amin (2016). This inquiry used a survey of the Pakistani construction company's workers by questionnaire. The experimental results showed that PMP is highly powerful and saves time and expense to better compete in the competitive market. In addition, the findings indicate that a major effect on the project performance is exerted by the PMP measures (PM leadership, PM KPIs and PM staff). This research would cover more factors, including PM relationship \& resources and PM lifecycle Processes, which should be analysed to assess the real project performance impacts of PMP. Therefore, the findings should be extended by expanding the theoretical framework and by covering more independent variables to generate more accurate results.

Hypothesis1: Project management performance has a significantly positive impact on project success.

\section{Project Management Performance and Project Risk Management}

Increasing the size of projects requires honest respect for risk management in order to appreciate a cross-disciplinary approach for PM (Naeem et al.,2018). The tracking of venture chances and project progress may be helpful through a fundamental risk management method. (Tippet \& Carbone, 2004). Risk reduction (RM) should end up as a lifestyle. The lack of thought or plan has to be marked with an endorsement. Especially if chance evaluations are assigned because their interest in knowledge is fair or unique, they appear to be adequate to reduce the money or physical risk (Ramirez-Cortés et al., 2012). Likewise, the wanders boss must also be accountable for carrying out walking risks as orchestrated in the case of a certain individual (Zwikael\&Smyrk, 2012,), but she/he is not necessarily responsible for getting the 
optimal conditions out of this. The performance of the project (PS) is a concept that is ambiguously defined, both in PMP literature and also in a project manager's emotion. Expand goals have traditionally been addressed as a triangle, time, cost, and highlights of quality are productive and pedantinetic, as they demonstrate how an improvement in one of the parts has to affect the other two (Naeem et al., 2018; Slevin\& Pinto, 1986).

PMP is the actual practises used to run a project, as stated previously in Chapter one. As project management services are therefore an important activity, evaluating its efficiency is also essential (Qureshi et al., 2009). Many studies included different steps for improving mixtures of plant and engineered projects, for example KPIs and benchmarking (Luu et al, 2008; Yun et al. 2016), evaluation models (Din et al., 2011; Qureshi et al., 2009). (Joslin\& Muller, 2015). However, considering the fact that the number of active projects (Davis 2016; Khan \&Rasheed 2015) is disturbingly small, and that many projects have still not been achieved (Joslin\&Muller 2015; Lehtonen\&Martinsuo 2006) since the project outcomes are still a disappointment for the parties concerned (Cooke-Davies, 2002).

However, in order to ensure best project results, risk management is still not considered appropriate and productive in projects (Chapman \& Ward, 2004). The greater management strength, the fewer risk factors are present (Zwikael\&Ahn, 2011). Moreover, there is a positive link between risk factors and project success management (El-Sayegh, 2008; Raz et al.,2002). In this respect, this management will reduce the impact on various project objectives (El-Sayegh, 2008; Shengli et al., 2008). However, the study of the involvement of risk factors in project ventures was a major breakthrough to prevent harm in results by Girardi, Rebachini \& Moutinho (2018) as the impact of risk factors on the execution of projects depends on RM strength and the skills of the risk managers. Moreover, it is urgent to address each of these risk factors in order to enhance project management and project performance, as well as how to connect them to infrastructure projects. The results were supported (Wu, et al. 2017), showing that an efficient PRM is directly linked to the achievement of the good project variables.

Hypothesis2: Project management performance has a significantly positive impact on project risk management.

\section{Project Risk Management and Project Success}

Project risk tends to be a result-based thought. It is, for the most part, used to demonstrate a possible, troublesome state of a task. In the meantime, it also has a tendency to be an errand related or objective-related thought (Naeem et al., 2018). A project can be grasped as a small framework (or affiliation) which is made to complete certain errands or achieve the particular goal (De Bakker et al., 2010; Lundin, 1995; Packendorff, 1995; Turner, 2006). The importance of project risk is coordinated towards the framework's assignments or goals. A project risk could be believed to be a possible disrupting impact, and its emergence could bring about take-offs from pre-set up framework goals, for instance, courses of action, quality, and impacts, and so forth. It very well may be found in the written work that an overall recognized significance of project risk is a capacity of deviation from pre-characterized objectives (Zhang, 2007). A project risk is described as "a dubious project chance occasion or condition that, if it happens, has a positive or negative effect on a project's targets" (Duncan, 2005). "Successful project culmination depends on all things considered, on the early distinguishing proof of impending dangers." (Datta\&Mukerjee, 2001). Carvalho\&Rabechini (2015) investigated the relationship between PRM and project success, considering the contingent impact of project 
complexity. Analyzing the existing literature review was used to underpin the conceptual framework, and then a questionnaire was used before performing an empirical validation using SEM. The experimental outcomes indicate that the combination of soft and hard skills has a significant correlation of the effect on project success, as the hard side of PRM covers only part of the managerial aspects of project uncertainties, but the soft side has a significant positive impact not only on the hard side of RM but also on project success. This study did not take the effect of the soft side on project success into considerations.

De Bakker et al. (2014) evaluated the impact of risk identification on project success using an experimental design, which is applied to a total of 53 project groups. The results showed that some organizations had used the PRM as an instrument by project managers to execute and to control the projects to alignment the results with project strategy. Consequently, the correspondence between project staff during risk identification plays a critical part in the connection amongst PRM and project success. However, more experiments are required to add more value to the relationship between PRM and project success. Other studies explored the impact of the PRM on the project success, like (De Bakker, Boonstra, \&Wortmann, 2011; Rabechini\& de Carvalho, 2013; Al-Shibly, Louzi, Hiassat, 2013; Carvalho\&Rabechini, 2015; Doskočil\&Lacko, 2018). Rabechini\& de Carvalho (2013) determined the impact of PRM on project success. The proposed research used a survey to explore 415 projects at different levels of complexity in various industrial sectors in several regions of Brazil. The experimental outcome showed that adopting risk management practices has a significant positive effect on project success. In detail, it demonstrated the importance of soft skill in risk management. While the project risk manager, constituted the second significant variable to understand the relationship between risk management and project success. The primary challenge the proposed study is suffered from is the sample size, where it must be larger to cover different countries and different type of projects to measure the real impact of PRM on projects performance and success.

Moreover, Al-Shibly et al. (2013) determined the impact of PRM on construction projects success from the owners' and employees' perspectives in Jordan. A questionnaire was used to collect data from (230) respondents, only (200) answer the questionnaire. The experimental results showed that there is an effect between both Risk identification and Risk assessment on project success, scheduled time, planned budget, and the capacity to consent to specialized particulars. In general, PRM is a standout amongst the most vital instruments in deciding any project success. Thus, the relation between PRM and the project's success is significant because most of the projects are operating in a very dynamic and rapidly changing environment. However, the primary challenge is the requirement that asks any project manager to understand the importance of PRM and the influenced of each part of the organization and build communication between staff and management. The above results are the same result of the study proposed by De Bakker et al. (2011), which explored the potential impact of different PRM activities on project success with regards to ERP usage projects. An interview was used as the primary method of data collection, separate interviews were held with various stakeholders from projects. The results indicated that the stakeholders consider risk identification as the general influential risk management activity. Further, PRM has a positive impact on project success regarding "on time, within budget," where the risk identification is, by all stakeholders, considered to be the most influential risk management activity of all, followed by risk reporting. However, more researches about the role of PRM including all of the possible variables on project success are urgently required. 
Hypothesis3: Project risk management has a significantly positive impact on project success.

\section{Mediating Role of Project Risk Management on Project Management Performance and Project Success}

Project risk management is a steady technique of recognizing, breaking down, organizing and intervening threats that cripple an exercises likelihood of success in regards to cost, plan, quality, thriving and specific execution (Naeem et al., 2018) Associations and proprietors regularly consider expanding risk management practices as "pleasant to have" on a project as opposed to a middle area of project controls. When you pick a project's significant risk things and their relative needs, you have to create of risk control abilities to bring the risk things under control. The primary stage in this system is to build up an instrument of risk administration arranges that spread out the activities fundamental to bring the risk things under control, for the product stream and consummation of the project (Mentis, 2014). The primary objective of using a project risk management is to increment organizational value (Dalcher, 2012). The critical question to consider is the way by which social contrasts influence the successful management of projects that traverse crosswise over cultures. In particular, multifaceted issues are presumably going to wind up distinctly and a vital component, as they have in the management of worldwide joint assignments. It is to get it the cultural contrasts for projects to be successful (Brannen, \& Salk, 2000). The organization can benefit from utilizing a PRM structure by expanding the adequacy of human exertion in the organization while expanding the effectiveness of these endeavors. In this manner, project success is estimated by its proficiency for the time being and its viability in accomplishing the standard outcomes in the medium and the long-term (Jugdev et al., 2001; Muller \&Jugdev, 2012). Therefore, the literature proposes that pre-planning Risk management mediates the PMP and project success.

Studies have recognized planning as one of the essential success factors in a project. Like this, splendid organizing builds the odds that the project will be authentically executed and end. The impact of fundamental envisioning corporate arranging has been tended to in a couple of surveys (Babafemi, 2015). Only 10 out of 15 exploratory audits have announced critical changes happening due to formal arranging works out (Bryson, Edwards\& Van Slyke,2018). Alternately, the results identifying with the impact of foreseeing undertaking achievement are generously less obscure. Moreover, De Bakker et al. (2014) examined the influence of risk identification on project success. The findings demonstrated that risk identification significantly and positively influences the project success. Also, Junior and de Carvalho, (2013) conducted a study that aimed at investigating the impact of project risks management on the project performance in Brazilian companies. They concluded that implementing effective risk management practices has a significant positive effect on the success of the project. They also found that the business environment and risk management techniques are critical factors affecting the project success. They also state that project managers and risk manager must cooperate to have a successful project. On the other hand, Hussein and Klakegg (2014) conducted a survey to collect empirical data about the frequency of existence of numerous risk factors related to the project management performance success. The correlation analysis concluded that there are four risk factors in the beginning phase that, if arising, will lead to the stay of these risk factors in the execution and assessment phase. Fernando et al. (2018) were used SEM to investigate the effect of project risk management (PRM) and PMP on the Project Success. The obtained results showed that the PRM has a positive association with PMP and the project success. Also, PRM is a key 
component of PMP and project success. The primary challenge of this study that the structural equation modeling technique does not define the relations nature between the variables; hence the results are not fully supported with robust analysis. According to the existing literature, there is a wide gap between risk management in theory and practice inside in the organizations, as well there is a conflict between the results of studies that proved that the PRM has a low effect on project performance. Other studies suggested to use moderate levels of PRM to decrease the negative effects of risk on project success.

Hypothesis4: Project risk management mediates the relationship between project management performance and project success.

\section{Methodology}

The study used a quantitative approach research with a descriptive research design. In addition, the population of this study is 457 ICT employees in the Ministry of Health (MOH) in Jordan (Ministry of Health, 2017). The sample size of this study is the 208 ICT employees of Ministry of Health in Jordan. Therefore, the sample increase to 400 to avoid the response error (Awang, 2016). The researcher used independently select a random sample from each stratum) to collect sample since it is the most effective method and a virtuous choice when distinguished information is needed mainly when the target population for this study has been known as the Ministry of Health in three regions in Jordan. Hence, Table 1 illustrated how this study selected the respondents of each Ministry according to the proportions of their employees to the sample size of the study.

Table 1 Proportion of the Sample

\begin{tabular}{ccccc}
\hline Region & MOH & $\begin{array}{c}\text { Number of } \\
\text { ICT } \\
\text { employes }\end{array}$ & $\begin{array}{c}\text { Percentage } \\
\text { employees by } \\
\text { Region } \%\end{array}$ & Proportions \\
\hline Middle & 14 & 216 & $\frac{216}{457} \times 100=47.2 \%$ & $\frac{47.2}{100} \times 400$ \\
North & 14 & 185 & $\frac{185}{457} \times 100=40.5 \%$ & $\frac{40.5}{100} \times 400$ \\
& & & & 162 \\
South & 4 & 56 & $\frac{56}{457} \times 100=12.3 \%$ & $\begin{array}{l}100 \\
=49\end{array}$ \\
Total & $\mathbf{3 2}$ & $\mathbf{4 5 7}$ & $\mathbf{1 0 0 \%}$ & $\mathbf{4 0 0}$ \\
\hline
\end{tabular}

\section{The Instrument (Questionnaires)}

The study was therefore carried out in Jordan, and the results were obtained by way of a selfgoverning questionnaire, where respondents were asked to complete the survey themselves. The goal of this study is to reduce costs with the elimination of the respondent of devices and things, including computer software (Willett, 2017). The adapted questionnaire is essentially a combination of various previous research instruments on this phenomenon. These questionnaires are adapted to provide a clear understanding of the phenomenon and constructs of this research study in Jordan. 


\section{Data Analysis}

The main purpose of this paper is to examine the mediating effect of Project Risk Management (PRM) on the relationship between Project Management Performance (PMP) and Project Success (PS) of ICT projects in the Jordanian healthcare sector. Structural Equation Model were used.

\section{Results and Discussion}

This section presented the results of the study and discusses the outcome. From 400 questionnaires administered, only 300 valid responses were obtained (representing $75.0 \%$ response rate). Thus, the analyses were based upon this 300 .

\section{The Pooled-CFA for all Measurement Model of Constructs}

Figure 1 presents the grouped structure. Here the measuring model has been validated with CFA procedure for all second-order constructs (Awang, 2015). The reason for the joint CFA for all constructs is to test the discrimination between structures in the model (Yusof et., 2017, Aziz et al., 2016; Mohamad et al., 2016; Afthanorhan et al., 2017). For all latent structures the product of the pooled CFA procedure is shown in Figure 1 . The results showed the fitness indexes for both models, the loading factor of each subconstruction or part tests the main structure and the correlation between the structures in the model. the results. The fitness indexes met the threshold values as shown in Figure 1 and for each object the factor loads exceed 0.6, and the correlation coefficient between each building does not exceed the threshold (0.85). The multi-collineary problem arises if the relationship between two buildings is higher than 0.85 . When you look at the correlation values (in the double-headed arrow) no more than 0.85 was found. Thus, there is no problem of multi-collinearity.

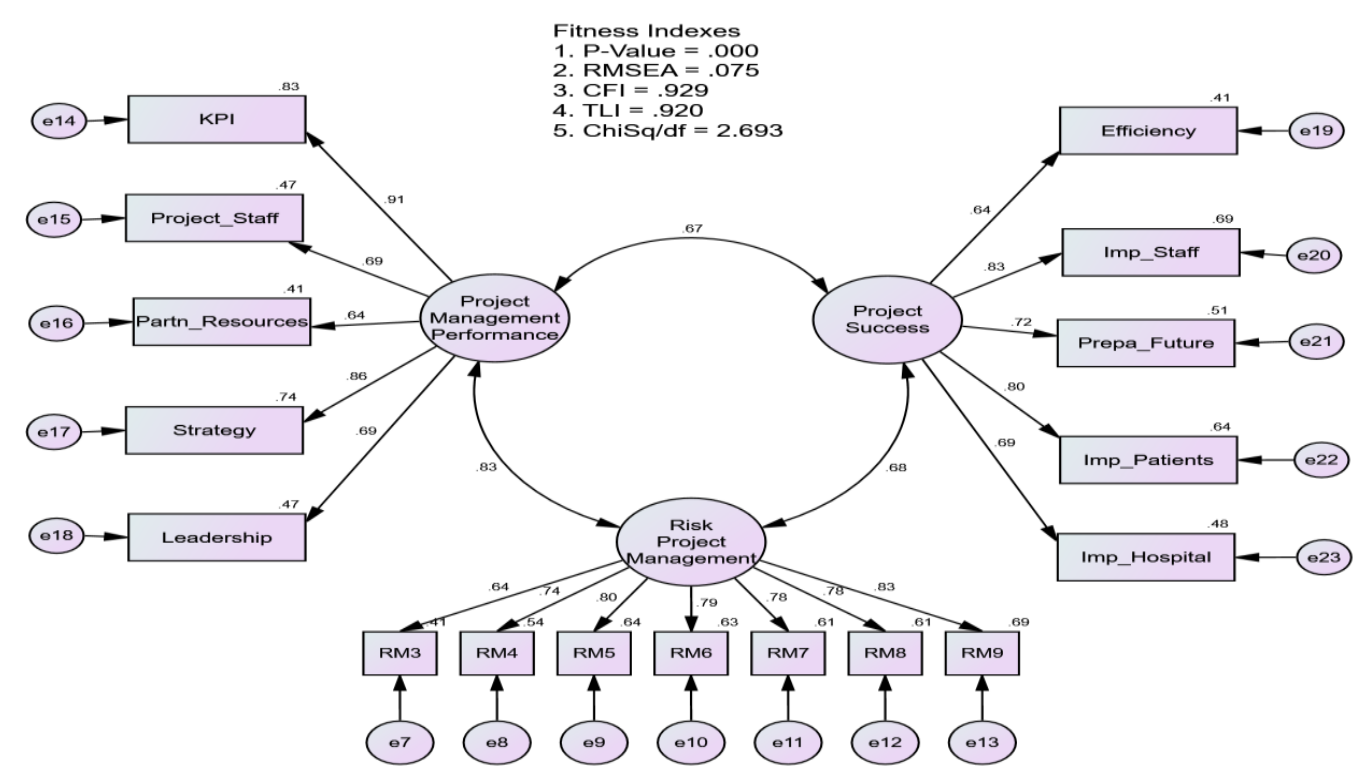

Figure 1 Pooled-CFA for all the Study Constructs 


\section{The Assessment for Construct Validity}

Figure 1 of the fitness indices meets the previously mentioned threshold values. The category of absolute fit is RMSEA 0.075 (under 0.08), category CFI of incremental fit is 0.929 (up to 0.90 ), category Parsimonious fit is 2.693, and the ration Chisq/df. The absolute fit is 0.075 (up to 0.08 ). (achieved the threshold of less than 3.0). Consequently, the model for measuring all latent constructions in Figure 4.6 met the construction validity criterion (Aziz et al., 2016; Mohamad et al., 2016; Yusuf et al., 2017).

\section{The Assessment for Convergent Validity and Composite Reliability}

The analysis must measure the average variance derived for the evaluation of converging validity (AVE). If its AVE reaches the 0.5 threshold value, it achieves convergent validity. The analysis needs to measure the CR in order to test the composite reliability and its value should excess the value of 0.6 to achieve the reliability (Aziz et al., 2016; Mohamad et al., 2016). Table 2 measures and shows the AVE and CR for both concepts.

Table 2 The Average Variance Extracted (AVE) and Composite Reliability

\begin{tabular}{|c|c|c|c|c|}
\hline Constructs & Items & Factor Loadings & $\begin{array}{c}\text { CR } \\
\text { (above 0.6) }\end{array}$ & $\begin{array}{c}\text { AVE } \\
\text { (above 0.5) }\end{array}$ \\
\hline \multirow[t]{6}{*}{ Project Management Performance } & & & 0.922 & 0.704 \\
\hline & PR & .800 & & \\
\hline & $\mathrm{L}$ & .786 & & \\
\hline & $\mathrm{S}$ & .760 & & \\
\hline & KPI & .938 & & \\
\hline & PST & .897 & & \\
\hline \multirow[t]{6}{*}{ Project Success } & & & 0.911 & 0.678 \\
\hline & IP & .938 & & \\
\hline & $\mathrm{E}$ & .633 & & \\
\hline & PF & .709 & & \\
\hline & $\mathrm{IH}$ & .960 & & \\
\hline & IS & .828 & & \\
\hline \multirow[t]{9}{*}{ Project Risk Management } & & & 0.933 & 0.635 \\
\hline & PPRM1 & .676 & & \\
\hline & PPRM3 & .695 & & \\
\hline & PPRM4 & .770 & & \\
\hline & PPRM6 & .790 & & \\
\hline & PPRM7 & .851 & & \\
\hline & PPRM8 & .851 & & \\
\hline & PPRM9 & .893 & & \\
\hline & PPRM10 & .824 & & \\
\hline
\end{tabular}

The study found that both AVE and CR values surpass their threshold values of 0.5 and 0.6 , respectively (Kashif et al. 2015) with regard to the Average Variance Extracted and Composite Reliability (CR) in Table 2, so that the study will find that convergent valuation and composite reliability have been achieved on all latent constructs of the model. 


\section{The Assessment of Discriminant Validity among Constructs}

Another validity of the model, i.e. discriminant validity, must be measured. The unequal validity evaluation ensures that the model does not include redundant constructs. When every pair of buildings in this model is strongly correlated, redundant builds take place. The discriminant validity index description as shown in Table 3 needs to be established to determine the discriminating validity. The diagonal values in bold are the square root of the AVE of each house, while other values constitute the coefficient of correlation among the pair of their constructs. The discrimination validity of each building is accomplished by exceeding the square root value of the AVE with other constructions of the model. The discrimination (Awang et al., 2015). This is, if the diagonal values (bold) are higher than all other values of its row or column, the Discriminant Validity can be obtained. The statistics in Table 3 have reached the Discriminant Validity criterion. The analysis thus establishes that Discriminant Validity is obtained for all structures.

Table 3 The Discriminant Validity Index Summary for all Constructs

\begin{tabular}{|c|c|c|c|}
\hline Construct & $\begin{array}{l}\text { Project } \\
\text { Success }\end{array}$ & $\begin{array}{c}\text { Project } \\
\text { Management } \\
\text { Performance }\end{array}$ & $\begin{array}{l}\text { Project Risk } \\
\text { Management }\end{array}$ \\
\hline Project Success & 0.823 & & \\
\hline $\begin{array}{l}\text { Project Management } \\
\text { Performance }\end{array}$ & 0.559 & 0.839 & \\
\hline Project Risk Management & 0.535 & 0.664 & 0.797 \\
\hline
\end{tabular}

\section{The Assessment of Normality for all Constructs}

Finally, before modelling the structural model and implementing SEM, the analysis must determine the normality distribution of all things that quantify construction. Since SEM employs the parametric statistical modelling approach, all items measurement of their respective constructions must be evaluated for normal distribution. The survey should only show that the values of skewing for all things do not vary from normality, as reported in Awang (2015), Kashif et al. (2016), Mohamad et al. (2016) and Yusuf et al. (2017). The skewing values are therefore appropriate for the range -2.5 to 2.5 . The skewness values for every variable in the model range from -2.5 to 2.5 , meaning its distribution does not vary from norm (Awang, 2015; Kashif et al., 2016; Yusuf et al., 2017). The data distribution thus satisfies the standard distribution criterion for the use of the parametric statistical analysis. The research will then begin to model the structural model after the criteria for validity, trustworthiness and normality distribution are fulfilled.

\section{Structural Equation Modelling (SEM)}

When the CFA report has been finalised, the researcher will find that the measurement models have been validated in all the latent constructs involved in the model, meeting all of the necessary thresholds for validity and reliability. The next step for the researcher is to incorporate such structures into the structural model so that structural equation modelling is carried out (SEM). The building should be organised from left to right, starting by the exogenous buildings in the far left, followed by the mediator buildings in the centre and the endogenous building in the far right (Yusuf et al., 2017). The researcher then connects the exogenous structure, by the single headed arrow, to its respective endogenous structure 
based on the path of the hypothesis. Finally, the double-headed arrow presented in Figure 2 links each exogenous structure. The single header arrow demonstrates the causal influence of an exogenous building on the respective endogenous constructs. If more than one exogenous construction is part of the structural model then the double heading arrow should be used to estimate the association effects between all exogenous structures. In order to avoid the multi-linearity problem in a model with high correlations between the two exogenous constructions the analysis needs to assess the strength of correlation among exogenous constructions. The link between a pair of exogenous constructions above 0.85 indicates a high correlation of the buildings and the multi-coordinarity problem in the (Yusof et al., 2017; Aziz et al., 2016; Mohamad et al., 2016). Figure 2 displays the coefficients of the regression path for all constructs.

The outcome of the regression analyses as shown in Table 4.31 indicates a regression path (beta-) coefficient for effects on the dependent building taken from Figure 4.18 of any exogenous building. The study indicates that the direct impact on project performance with the path coefficient of Beta $(0,26), p=0,001$ ) and critical ratios ( $t$-values) $=3,185$, was positive and statistically important. This results in a project progress increase of 0.26 as the efficiency of Project Management is improved by one unit. This finding was consistent in the hypothesis model and supports Hypothesis 1, which notes that "The performance of the project management has significant effects on the success of the project." This finding demonstrated the direct significant impact of Project Progress on project management efficiency. Again, the findings of the study show that for the success of the project management, the project risk management with a direction coefficient (Beta) $=0,80, p=0,000$ ) has a statistically important indirect effect and the crucial ratios (t-values) $=14,121$. The result showed that for each unit the efficiency of project management was increased; the project risk management would lead to 0.80 increases. Therefore, the hypothesised model (Hypothesis 2), which notes that "project management performance has important impacts on project risk management," was endorsed. The influence of the project risk management on project performance is another significant link between the variables in the model. The findings showed in Table 4.31 show that the path coefficient (bette) $=0.29, p=0.000$ ) was statistically important, and that there were critical ratios ( $t$-values) $=3.437$. Hypothesis No 3 was then acknowledged, which claimed that "Project risk management has major effects on project success." 


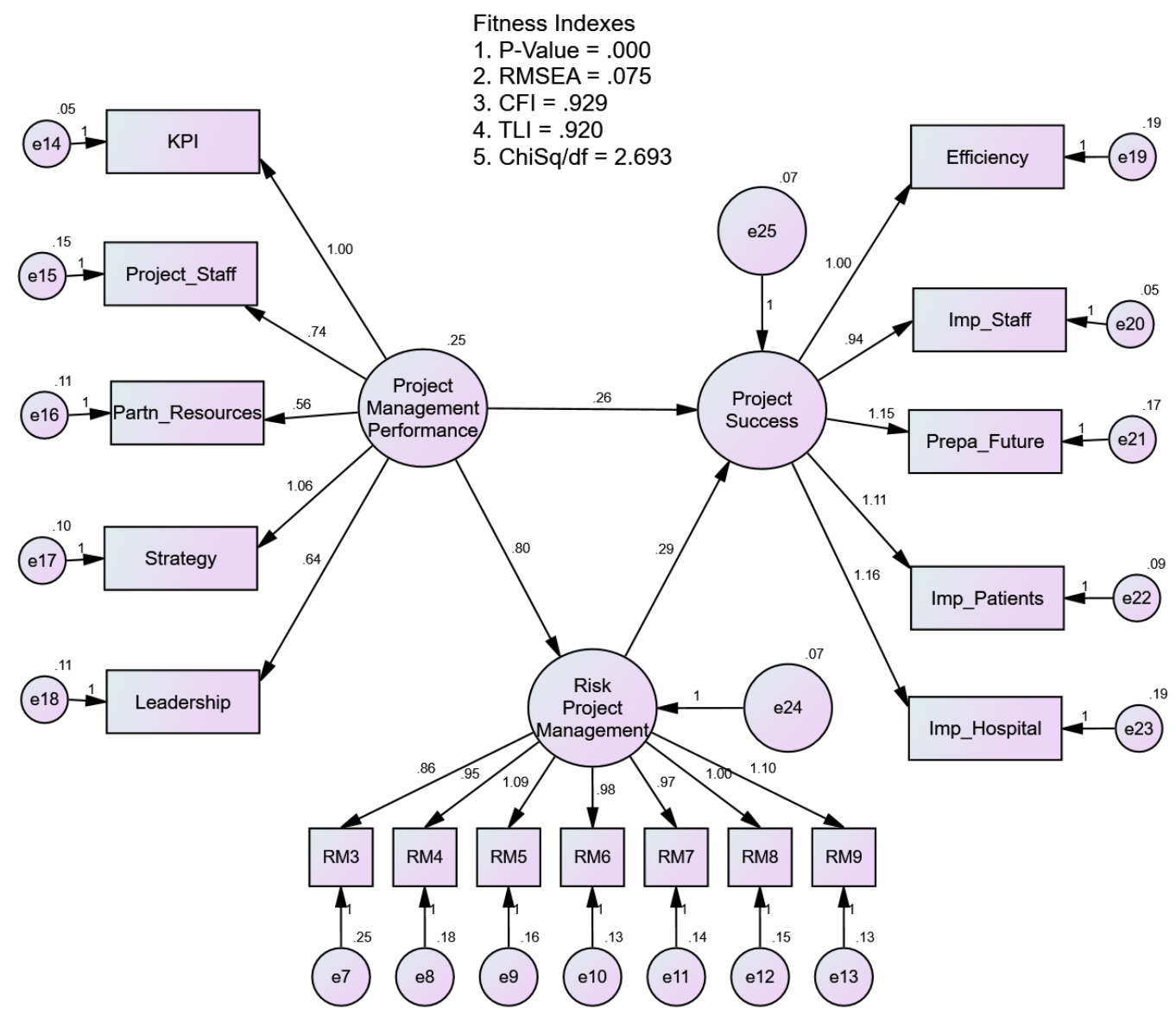

Figure 2 Regression Path Coefficient among constructs in the model

Table 4 The Regression Path Coefficient

\begin{tabular}{|c|c|c|c|c|c|c|}
\hline Hypothesis & & Beta & S.E. & C.R. & $\begin{array}{l}\text { P- } \\
\text { Value }\end{array}$ & Result \\
\hline \multirow[t]{2}{*}{$\mathrm{H}_{1}$} & Project Management & & & & & \\
\hline & $\begin{array}{l}\text { Performance } \rightarrow \text { Project } \\
\text { Success }\end{array}$ & 0.257 & 0.081 & 3.185 & 0.001 & Significant \\
\hline \multirow[t]{2}{*}{$\mathrm{H}_{2}$} & Project Management & & & & & \\
\hline & $\begin{array}{l}\text { Performance } \rightarrow \text { Project } \\
\text { Risk Management }\end{array}$ & 0.804 & 0.057 & 14.121 & 0.000 & Significant \\
\hline $\mathrm{H}_{3}$ & $\begin{array}{l}\text { Project Risk Management } \rightarrow \\
\text { Project Success }\end{array}$ & 0.292 & 0.085 & 3.437 & 0.000 & Significant \\
\hline
\end{tabular}


Table 4 gives an explanation of the model's performing R2 (coefficient of determination) (figure 2). The squared multiple correlation (R2) coefficient for latent variables was analysed in order to analyse the amount of variance in the latent variables explained by the model. The results showed that statistically significant variance for endogenous variables was explained in the hypothesised models (Project Success). The R2 value of the relationship between the success of the project and the risk management of the projects was $=0.34$, which means that 750 percent of the variance in the endogenous variable was explained in exogenous variables (project management) (Project Risk Management). Other predictors not captured in the model could reflect the remaining 66 percent of the variance in the dependent variable while other exogenous variables not captured in the model will account for the other 25 percent.

Table 5 The R2 and its implication in this study

\begin{tabular}{lcl}
\hline $\begin{array}{l}\text { Endogenous } \\
\text { Construct }\end{array}$ & $\mathrm{R}^{2}$ & \multicolumn{1}{c}{ Conclusion } \\
\hline $\begin{array}{l}\text { Project } \\
\text { Success }\end{array}$ & 0.50 & $\begin{array}{l}\text { The Project Management Performance and Project Risk } \\
\text { Management by the respondents contribute about } 34 \\
\text { percent of Project Success }\end{array}$ \\
$\begin{array}{l}\text { Project Risk } \\
\text { Management }\end{array}$ & 0.70 & $\begin{array}{l}\text { The Project Management Performance contribute about 75 } \\
\text { percent of Project Risk Management. }\end{array}$ \\
\hline
\end{tabular}

Testing the Project Risk Management as a mediator in the Relationship between Project Management Performance and Project Success

Three steps are followed to test the mediation effect. Phase one affirmed the value of the direct effect, while Step two explored the relevance of the indirect effect. The last step is to evaluate the strength and importance of the effect as a whole. There is therefore a presence of mediation where both indirect and direct impacts are significant. Whether there is not a significant indirect effect, so there is no mediating effect, but if there is no significant indirect effect, but no direct effect, then partial mediation is accomplished. The direct influence on the relationship between the project management efficiency and the progress of the project can be seen based on the findings from Table 6 (Beta $=0.27, p=0.035$ ). The relationship between project management and Project risk management (beta=0.86, $p=0,000$ ) is significant for the indirect effect and the result was significant for project risk management (beta $=0.33, p=0.009$ ). The overall impact is nevertheless substantial (Sum of indirect effects) (Beta=1.19, $p=.000$ ). Therefore, since the strength of the relationship (total effect) is greater (Beta=1.19) than the direct effect, which is significant (Beta $=0.27, p=0.035$ ), the relationship between the Project Risk Management and Project Performance can be inferred that in part this intermediate is important. This result is therefore supportive of hypotheses 4. 
Table 6 Mediation Effect of Project Risk Management on Relationship between Project Management Performance and Project Success is significant

\begin{tabular}{|c|c|c|c|c|}
\hline Construct & & Beta & $p$ & Result \\
\hline \multicolumn{5}{|l|}{ Direct Model } \\
\hline Direct effect & $\begin{array}{l}\text { Project Management Performance } \\
\rightarrow \text { Project Success }\end{array}$ & 0.26 & 0.001 & Sig \\
\hline \multicolumn{5}{|l|}{ Mediation } \\
\hline \multirow[t]{2}{*}{ Indirect effect } & $\begin{array}{l}\text { Project Management Performance } \\
\rightarrow \text { Project Risk Management }\end{array}$ & 0.80 & 0.000 & Sig \\
\hline & $\begin{array}{l}\text { Project Risk Management } \rightarrow \text { Project } \\
\text { Success }\end{array}$ & 0.26 & 0.009 & Sig \\
\hline \multirow[t]{2}{*}{ Total effect } & Project Risk Management $\rightarrow$ Project & 1.09 & 0.000 & Sig \\
\hline & $\begin{array}{l}\text { Management Performance } \quad \rightarrow \\
\text { Project Success }\end{array}$ & & & \\
\hline Conclusion & Partial mediation ( $\left(\mathrm{H}_{4}\right.$ accepted $)$ & & & \\
\hline
\end{tabular}

\section{Discussion}

In developing the methodology for this research, this paper used a quantitative method. Research data are collected by means of survey surveys. Firstly, does this paper examine whether the performance of projects in the Jordan healthcare sector significantly contributes to the project's success? The results of the empirical study indicate that the performance of project management has a positive effect on project success. Considerable research shows that the success of the project is highly dependent on the performance of the project they have offered (Aftab, Sarwar, Sarwar and Amin, 2016; Samarah and Bekr, 2016; Fernando et al,.2018). This study shows that interest in these terms exploded when the corporate strategies and the policy agenda came into being. The competitive burden on business has increased with internationalisation and globalisation. The results show that the main factors that influence the success of the project are project management performance. The main responsibility for the effectiveness and effectiveness of the project and all its resources is Project Management Performance to ensure that the project is at the end successful. If project output has proper project management expertise, experience will create a culture relevant to the project, develop good customer relationships, and take the right approach, then the project goal will definitely be helpful. This study finding concerns Christenson and Walker in 2004 and Mir \& Pinnington in 2014. PM employees are also the person who plays the greatest part in a project. Successful project requires proper guidance and training in smart handling. For this reason, the performance of project management has a positive effect on the progress of the project. Current research results support the findings of previous researchers who argue that project The output of management is an important part of the success of any project (Mir \& Pinnington, 2014; Stefanovic \& Shenhar, 2007). Based on the theory of RBV (Porter, 1996), RBV theory is the first to determine that PMP resources are the basis for competition advantage in explaining relations between variables in order to optimise the use of organisational resources in order to realise their full potential. RBV Theory (Almarri \& Gardiner 2014). In addition, it was seen that RBV was a good organisation.

In addition, secondly, this article explores the performance of project management and makes a substantial contribution to project risk management in Jordanian healthcare 
project ICT? Based on the results, the proper application of the project management framework generates an organization's holistic added value both at strategic and organisational level. Effective risk management requires, in other words, to be clearly defined in order to avoid strategic failures which can result in organisation. Five integrated elements further help an organization's capacity to manage uncertainties, take part in good corporate management and implement new regulatory changes. There is also a closely related and often exceedingly rare phenomenon not quantifiable by statistics or forecasting methods. This may be the product of culture, action and perception. Some people have a different behaviour than others, so it's seen as needless overhead; some do it more than others do or some do not at all do it. Human understanding therefore plays an important role in effectively carrying out the risk management process. Project decisions must take into account the level of risk within the project. Consequently, risk management plays an important role in all decisionmaking. The risk and its effect on project priorities must be fully informed of by project managers and all risk-infected parties. Projects are multi-faceted and dynamic and need to take sufficient risk management consideration to adopt a multiciplinary project management strategy. A major risk management tool can help to track the prospects of projects and optimise the success of businesses. (Tippett \& Carbon, 2004).

On the other hand, the study of risk factors present in projects was considered, by Girardi, Rebechini and Moutinho (2018), to be a significant step towards the prevention of performance harm because the influence of risk factors on project performance depends on the strength of risk management and the abilities of risk managers, but the complexity of the project is no different. This result is in line with other comprehensive theoretical and empirical research in the field of Alkhlaifat, Abdullah and Magassouba (2019), Rabechini Junior, and Monteiro de Carvalho, (2013). The result therefore confirms the Modern Portfolio Theory, which shows that systematic portfolio risk evaluation reduces the number of errors and helps to create consensus on risk in line with the organisational strategy in collaboration between management and senior management.

Thirdly, this paper looked at the effect of the project risk management, whether it is necessary for the success of the project for ICT projects in the Jordanian healthcare sector? A project risk could be regarded as a potential troubling force, and the presence of the project could lead to startups from pre-set process objectives including steps, results and effects, etc. The importance of project risk in successful projects can be found in many recognised texts to recognise any deviation from the predefined projects' objectives (Zhang, 2007). A project risk is defined as a "a dubious opportunity for a project or condition that it has a positive or negative impact on the goals of a project if it happens off chance" (Duncan, 2005). "To a large extent, successful completion of the project depends on early detection of immediate risks " (Datta \& Mukerjee, 2001). Additional research has investigated the effects of PRM (Projet Risk Management), such as: (De Bakker, Boonstra \& Wortmann, 2011; Rabechini \& de Carvalho, 2013; Al-Shibly, Louzi, Hiassat, 2013; Carvalho \& Rabechini, 2015; Doskočil \& Lacko, 2018). Rabechini and de Carvalho nevertheless determined the effect of project risk management on project performance (2013). The research results have shown a positive and important effect on project performance in carrying out risk management strategies. Al-Shibly and others (2013) further determined from the point of view of owners and employees the impact of the project risk management on performance of ICT projects in Jordan. Empirical studies have shown that project risk management has a positive impact on the performance of the project. The above results are the same findings from De Bakker et al. (2011)'s study that 
explored the potential effect on the performance of the project on ERP implementation projects of various project risk management practises.

Finally, this paper explored the mediating impact of Project Risk Management on Project Success and Project Erfolg on ICT projects in the Jordanian health sector. This empirical research using Baron and Kenny's (1986) approach to testing mediation shows that the relationship between project management and project performance can be mediated partly by project risk management. The indirect impact on project management efficiency and project progress is consistent with the empirical work project management (Haq, Liang, Gu, Du, \& Zhao, 2018; and Al-Abrrow, Alnoor, \& Abbas, 2019). These findings also support risk management for projects in terms of expense, policy, efficiency, well-being and professional development as an on-going mechanism for threat identification and assessment, planning and mediation of project actions. The primary goal of an organisational value increase is to use a risk management project. The central issue is to what extent social differences affect the successful management of intercultural ventures. Multifaceted issues in particular, when they resolve global joint tasks, would likely weaken a clearly important problem. The problem is to provide effective cultural differences for projects. By improving the productivity of the human work of the organisation, the company will benefit from using a system for project risk management and increasing its performance. The success of the project is therefore measured by its short-term performance and productivity to achieve the anticipated medium and long-term results. In addition, the findings indicate that project risk management has an important and optimistic effect on project performance. It also concluded that there is a substantial positive effect on project performance with the implementation of effective risk management practises. Company and risk control strategies are also important factors that impact the project's progress. However, in order to examine the effects of PRM and PMP on project performance, Fernando et al. (2018) has used structural equation models. The results showed that the PRM has a positive correlation with PMP and project progress. Furthermore, PRM is an integral part of PMP and project development. According to the current documentation, there are significant differences among organisations between theoretical and project risk management because the results of studies show the low impact of PRM on project performance.

A significant number of employees of ICT projects in the healthcare area of Jordan have taken part in this research. The study showed and interested result that the effects of project management success on ICT projects in the Jordanian healthcare sector were mediated by risk management. Project management efficiency had a positive and important effect on project progress as well. Despite this critical partnership, the findings have shown that the performance of project management has an effect on project risk management and project risk management has an impact on the progress of projects. Project risk management is also one of the prerequisites for achieving a successful project. This study verified the role of project risk management in influencing project management's positive effect on project performance. In considering project risk management, project managers transmit positive feedback to outside world which helps to gain an understanding of ICT projects in the Jordanian healthcare sectorln order to enhance project management efficiency and project progress it is crucial that ICT projects in Jordanian medical services recognise and resolve their employees' most important needs. The results showed the value of the five-dimensional construction of project management efficiency. These five dimensions also have different effects on the variable dependent and mediating. 
More market rivalry gives greater importance to the success of the project as a means of achieving competitive advantage. This heightened rivalry contributed to the global competition for research and development among several manufacturing sectors. In this sense, the close ties between project results and project progress are important to them. Industries that take appropriate steps to boost project progress are better prepared to handle the emerging reality that will take shape in the near future. The study results show the value of project management efficiency as a key factor for both project management performance and project progress in the ICT health sector. The literature relationship (e.g., this report, and the Serrador and Pinto (2015) study) focused on the conventional and agile performance of the project management as assessed by iterative preparation during the entire project process. The aim of this research is to bridge the few information gaps that are prevailing in the study of project performance. Most past research has covered only key project success determinants, such as project management efficiency, the management of project risk and ignoring the interrelationships of all these histories and their cumulative effect on project success. While the results of the study show that the effect of project management and progress is not direct, managers do need to concentrate on improved project management efficiency and project risk management constructs. The performance of project management in an industry will do a lot to attract top management, which in turn leads to the management of project risk by workers and can ultimately lead to greater project success. A good performance in project management and the reputation of an industry are appealing to projects because they would expect to have better job chances with such project management performance and prestige. Achieving international standards for project management efficiency is a long and tough process that involves an engagement with excellence in the achievement of project success and quality research. In terms of the relationship between project performance and project risk management, it should be emphasised here that project management performance has a significant direct effect on project progress, in line with other studies (e.g. Rabechini Junior, Monteiro de Carvalho, (2013); Alkhlaifat, Abdullah, and Magassouba, 2019). Given this connection, project risk management continues to be a significant factor in enhancing the success of projects and the ability to support healthcare ICT projects. The study thus shows that there is a relationship between the performance of project management and project risk management and, in turn, the success of such constructs.

\section{Conclusion and Recommendation}

This research has shown the value of project management and risk management in enhancing ICT healthcare project performance. The project success of the ICT health sector is one of the ways to enhance the industry success of project management results. Project managers need to look for ways to boost their industries' performance. The criteria and aspirations of managers should be taken into account to establish a successful project performance for industries. The obvious implications of these results are that the institutional marketing unit can improve the project success of extra-curricular activities and encourage them, in particular through social media, to increase project success for the applications or registration in an industry. This study could benefit from ICT initiatives in the Jordanian health sector, as the thesis relates to it in practise. In the Jordanian health sector managers' ICT projects should ensure that all project management factor factors are preserved and strengthened in order to meet the requirements of industrial companies of ICT projects in the Jordanian health sector. In addition, the importance of project performance management factors in developing 
the project success should be seen by ICT projects in Jordan's health care sector. It is supposed to be more likely to help consumers (patients) and to spread good words - in their own words - if they are happy with their services. This research offered empirical evidence for this assumption: the performance of project management had a substantial positive influence on project progress. Further implementation of project management efficiency variables can contribute to greater project progress, allowing clients (patients) stay in Jordan's ICT projects and suggest the industries to others. ICT initiatives in the Jordanian health sector should therefore concentrate on maintaining a high degree of customer satisfaction in order to create positive customer ties.

In Jordan, ICT ventures must, however, take the need of customers to fulfil their needs into account. More customers could visit the industries in this way. In Jordanian healthcare, if ICT ventures provide the consumers with good facilities, they will be happy and will be more competitive in the future. It could add more to their income output by retaining their customers. The more consumers are therefore, the more sales the advertisement expenses are reduced. As well, this will enable managers to consider the varying consequences of each project management success and project risk management practise so that they will achieve a competitive edge in ICT projects in the Jordanian health sector. In order to obtain better perspectives, it is also beneficial to extend the reach of research into more contextual differences such as region, types of equipment, size, age and company management style.

\section{Theoretical and Contextual Contributions}

The findings of this study have numerous implications for theory. First, this study contributes to the knowledge by adopting theoretical model from theories of Resource-Based View Theory (RBV), Modern Portfolio Theory (MPT) and Contingency Theory to assess the direct and indirect links between project management performance and project success through the mediating effect of project risk management. These theories have been extensively used to examine human behaviour in various past studies (De Bakker, Boonstra, \&Wortmann. (2012); Al-Shibly, Louzi, Hiassat (2013); Carvalho \&Rabechini Junior, (2015); Bekr\&Samarah (2016); Fernando, Walters, Ismail, Seo\&Kaimasu (2018); Girardi, Rabechini Junior \& Moutinho, (2018). However, adopting these theories alone has provided more comprehensive understanding of the cognitive processes and behaviours related to project success, project management performance, project risk management ICT projects in the Jordanian healthcare sector. In some studies, they have used this theory separately or in combination with others. This approach is likely to ensure a stable theory development. This result demonstrates the need to incorporate constructs beyond employees perceived project management performance in the model of project success, and suggest the need to extend existing theories of RBV, MPT and contingency to incorporate contingency relationships. Furthermore, this study concentrates on the relationship between project management performance and project success in a developing country setting (ie, Jordan). It is believed that little research has been done in developing countries particularly Jordan. Since the developing countries differs from developed countries in terms of social, political, cultural administrative and economic characteristics, such as the nature of the economy (Palekar, 2012). It is obvious that the differences between developed and developing countries' cultures may impact the outcome. Moreover, the research also in very specific areas of the world, many studies have been done in different locations of the world such as Africa, America, Europe, however, but not many in Asia. Still no similar study has ever been reported to have been conducted in Jordan. The findings of this study therefore, would contribute to 
the existing literature by enriching our understanding of the relationship between project management performance, project risk management, and project success in Asian context. Finally, the result of the mediation effect of project risk management contributes to the body of knowledge by leveraging the role of project management performance constructs on maintaining project success in the context of in ICT projects in the Jordanian healthcare sector.

\section{References}

Abu-Shanab, E., \& Al-Saggar, A. (2013). Reasons behind IT project failure: The case of Jordan. In Business strategies and approaches for effective engineering management ( $\mathrm{pp} .188$ 202). IGI Global.

Abu-Shanab, E., Al-Sebae, M., \& Hammouri, Q. (2016). Justifying the Investment of Information Technology Projects: A Case Study from Jordan. The 15th Scientific Annual, 55.48-52.

Aftab, J., Sarwar, H., Sarwar, H., \& Amin, S. U. (2016). Influence of Project Management Performance Indicators on Project Success in Construction Industry of Punjab, Pakistan.

Afthanorhan, A., Awang, Z., Fazella, S. (2017), Developing the patients' loyalty model for medical tourism industry: The case of Malaysia. International Journal of Society Systems Science, 9(2), 139-164.

Al-Abrrow, H., Alnoor, A., \& Abbas, S. (2019). The effect of organizational resilience and CEO's narcissism on project success: Organizational risk as mediating variable. Organization Management Journal, 16(1), 1-13.

Albogamy, A., Scott, D., Dawood, N., \& Bekr, G. (2013). Addressing crucial risk factors in the Middle East construction industries: a comparative study of Saudi Arabia and Jordan. In Sustainable Building Conference Coventry University, West Midlands, UK.

Al-Khamaiseh, Z. D., Halim, B. B. A., Mohamad, W., Afthanorhan, A., Alqahtani, A. H., \& Alkhlaifat, B. I. (2019). Exploring and Developing Items Measuring Goal Setting In the Context of Jordan Telecommunication Sector. INTERNATIONAL JOURNAL OF ACADEMIC RESEARCH IN BUSINESS AND SOCIAL SCIENCES, 9(12).

Alkhlaifat, B., \& Alshaweesh, R. (2017). The Impact of Service Quality and Relationship Quality on E-Advertising Success: Knowledge Management as a Moderator. International Journal of Academic Research in Economics and Management Sciences, 6(3).

Alkhlaifat, B., Tambi, B. A., \& Mansour, A. (2017). Factors Affecting Consumers' Trust Towards E-Commerce: Evidence from Jordanian Students' Perspective. European Journal of Business and Management, 9(11).

Alkhlaifat, B., Abdullah, A. A., \& Magassouba, S. M. (2019). Modeling Impact of Project Management Performance with Among Roles of Project Risk Management and Organizational Culture on Project Success. European Journal of Business and, 11(36).

Almarri, K., \& Gardiner, P. (2014). Application of resource-based view to project management research: supporters and opponents. Procedia-Social and Behavioral Sciences, 119(7), 437-445.

Al-Moumani, A. (2000) 'Construction delays: a quantitative analysis', International Journal of Project Management, Vol. 18, No. 4, pp.51-59.

Al-Shibly, H. H., Louzi, B., \& Hiassat, M. A. (2013). The impact of risk management on construction projects success from the employees perspective. Interdisciplinary journal of contemporary research in business, 5(4), 12-42. 
Altahtooh, U. A., \& Emsley, M. W. (2015). IT projects: Classifying risk factors and identifying project outcomes. Journal of Industrial and Intelligent Information Vol, 3(3).

Assbeihat, J. M. (2016). Factors Affecting Delays on Private Construction Projects. Technology, 7(2), 22-33.

Awang, Z., Ahmad, J. H., \& Zin, N. M. (2010). Modelling job satisfaction and work commitment among lecturers: A case of UiTM Kelantan. Journal of Statistical Modeling and Analytics, 1(2), 45-59.

Awang, Z. (2012). Research methodology and data analysis. Penerbit Universiti Teknologi MARA Press.

Awang, Z., Afthanorhan, A., \& Mamat, M. (2016). The Likert scale analysis using parametric based Structural Equation Modeling (SEM). Computational Methods in Social Sciences, 4(1), 13.

Aziz, MI., Afthanorhan, A., Awang, Z. (2016), Talent development model for a career in Islamic banking institutions: ASEM approach. Cogent Busines and Management, 3(1), 1186259.

Babafemi, I. D. (2015). Corporate strategy, planning and performance evaluation: A survey of literature. Journal of Management, 3(1), 43-49.)

Badewi, A. (2016). The impact of project management (PM) and benefits management (BM) practices on project success: Towards developing a project benefits governance framework. International Journal of Project Management, 34(4), 761-778.

Bannerman, P. L. (2008). Defining project success: A multilevel framework. In Proceedings of the Project Management Institute Research Conference (pp. 1-14).

Baron, R. M., \& Kenny, D. A. (1986). The moderator-mediator variable distinction in social psychological research: Conceptual, strategic, and statistical considerations. Journal of personality and social psychology, 51(6), 1173.

Brannen, M. Y., \& Salk, J. E. (2000). Partnering across borders: Negotiating organizational culture in a GermanJapanese joint venture. Human relations, 53(4), 451-487.

Bryde, D. J. (2003). Modelling project management performance. International Journal of Quality \& Reliability Management, 20(2), 229-254.

Bryde, D. J. (2008). Perceptions of the impact of project sponsorship practices on project success.International Journal of Project Management 26 (8), 800-809.

Bryson, J. M., Edwards, L. H., \& Van Slyke, D. M. (2018). Getting strategic about strategic planning research.

Cabral, J. S. (2017). Project Risk Management Strategies for IT Project Managers.

Carbone, T. A., \&Tippett, D. D. (2004). Project risk management using the project risk FMEA. Engineering Management Journal, 16(4), 28-35.

Carvalho, M. M. D., \& Rabechini Junior, R. (2015). Impact of risk management on project performance: the importance of soft skills. International Journal of Production Research, 53(2), 321-340.

Carvalho, M. M., \& Rabechini, R. (2017). Can project sustainability management impact project success? An empirical study applying a contingent approach. International Journal of Project Management, 35(6), 1120-1132.

Channar, Z. A., Talreja, S., \& Bai, M. (2015). Impact of human capital variables on the effectiveness of the organizations. Pakistan Journal of Commerce and Social Sciences, 9(1), 228.

Chapman, C., \& Ward, S. (2004). Why risk efficiency is a key aspect of best practice projects. International Journal of Project Management, 22(8), 619-632. 
Christenson, D., \& Walker, D. H. (2004). Understanding the role of "vision" in project success. Project Management Journal, 35(3), 39-52.

Cleland, D. L., \& Ireland, L. R. (2006). Project management.McGraw-Hill Professional.

Collins, J. C., \& Porras, J. I. (2005). Built to last: Successful habits of visionary companies. Random House.

Cooke-Davies, T. (2002). The "real" success factors on projects. International journal of project management, 20(3), 185-190.

Cooke-Davies, T. (2004). Project management maturity models. The Wiley guide to managing projects, 1234-1255.

Dalcher, D. (2012). Project management for the creation of organizational value.Project Management Journal, 43(3), 79-79.

Datta, S., \& Mukherjee, S. K. (2001, June). Developing a risk management matrix for effective project planning-- an empirical study. Project Management Institute.

Davis, K. (2016). A method to measure success dimensions relating to individual stakeholder groups. International Journal of Project Management, 34(3), 480-493.

De Bakker, K., Boonstra, A. \& Wortmann, H. (2011). Risk management affecting IS/IT project success through communicative action. Project Management Journal, 42(3), pp. 75-90.

De Bakker, K., Boonstra, A., \& Wortmann, H. (2014). The communicative effect of risk identification on project success. International Journal of Project Organisation and Management, 6(1-2), 138-156.

De Bakker, K., Boonstra, A., \&Wortmann, H. (2010). Does risk management contribute to IT project success? A meta-analysis of empirical evidence. International Journal of Project Management, 28(5), 493-503.

De Carvalho, M. M., Patah, L. A., \& de Souza Bido, D. (2015). Project management and its effects on project success: Cross-country and cross-industry comparisons. International Journal of Project Management, 33(7), 1509-1522.

Department of statistics, Jordan Statistic Year book (2017), Available from: http://dosweb.dos.gov.jo/products/statistical_yearbook2017/

Din, S., Abd-Hamid, Z., \& Bryde, D. J. (2011). ISO 9000 certification and construction project performance: The Malaysian experience. International Journal of Project Management, 29(8), 1044-1056.

Doskočil, R., \& Lacko, B. (2018). Risk Management and Knowledge Management as Critical Success Factors of Sustainability Projects. Sustainability (2071-1050), 10(5).

Duncan, W. (2005). Project Management Institute. A Guide to the Project Management Body of Knowledge.

El-Sayegh, S. M. (2008). Risk assessment and allocation in the UAE construction industry. International journal of project management, 26(4), 431-438.

Fabricius, G., \& Büttgen, M. (2015). Project managers' overconfidence: how is risk reflected in anticipated project success?. Business Research, 8(2), 239-263.

Fernandes, G., Ward, S., \& Araújo, M. (2015). Improving and embedding project management practice in organisations-A qualitative study. International Journal of Project Management, 33(5), 1052-1067.

Fernando, Y., Walters, T., Ismail, M. N., Seo, Y. W., \& Kaimasu, M. (2018). Managing project success using project risk and green supply chain management: A survey of automotive industry. International Journal of Managing Projects in Business, 11(2), 332-365. 
Fraser, M., Castrucci, B., \& Harper, E. (2017). Public health leadership and management in the era of public health 3.0. Journal of Public Health Management and Practice, 23(1), 9092.

Girardi, L. R., Rabechini Junior, R., \& Moutinho, J. D. A. (2018). Characterization of risk factor management in infrastructure projects. Gestão \& Produção, 25(1), 30-43.

Haq, S. U., Liang, C., Gu, D., Du, J. T., \& Zhao, S. (2018). Project governance, project performance, and the mediating role of project quality and project management risk: an agency theory perspective. Engineering Management Journal, 30(4), 274-292.

Hoque, A. S. M. M., \& Awang, Z. (2016). Exploratory Factor Analysis of Entrepreneurial Marketing: Scale Development and Validation in the SME context of Bangladesh. In AND TOURISM RESEARCH CONFERENCE 20-22 APRIL 2016 (p. 22).

Hoque, A. S. M. M., Awang, Z., \& Siddiqui, B. A. (2017). Technopreneurial Intention among University Students of Business Courses in Malaysia: A Structural Equation Modeling. International Journal of Entrepreneurship and Small \& Medium Enterprise (IJESME), 4, 1-16.

Hoque, A. S. M. M. (2018). Does government support policy moderate the relationship between entrepreneurial orientation and Bangladeshi SME performance? A SEM approach. International Journal of Business Economics and Management Studies, 6(3), 37-59.

Humaidi, N., \&Asarani, N. A. M. (2012). Investigation on Project Management Performance UsingKnowledge Project Management PerformanceAssessment Model: A Pilot Study. International Journal of Innovation, Management and Technology, 3(6), 769.

Hussein, B. A., \& Klakegg, O. J. (2014). Measuring the impact of risk factors associated with project success criteria in early phase. Procedia-Social and Behavioral Sciences, 119, 711-718.

Watt, A. (2014). Risk Management Planning. A. Watt, Project Management, 150-158.

Idoro, G. I. (2012). Influence of project plans on the outcome of construction projects procured by Design-Build (DB) in Nigeria. Journal of Construction in Developing Countries, 17(2), 81-103.

Joslin, R., \& Müller, R. (2015). Relationships between a project management methodology and project success in different project governance contexts. International Journal of Project Management, 33(6), 1377-1392.

Jugdev, K., \& Müller, R. (2005). A retrospective look at our evolving understanding of project success. Project management journal, 36(4), 19-31.

Jugdev, K., Mathur, G., \& Fung, T. (2011, July). Project management assets and project management performance: Preliminary findings. In Technology Management in the Energy Smart World (PICMET), 2011 Proceedings of PICMET'11: (pp. 1-7). IEEE.

Jugdev, K., Thomas, J., \& Delisle, C. (2001). Rethinking project management-Old truths and new insights.Project Management Association Finland/Norwegian Project Management Forum.

Kashif, M., Awang, Z., Walsh, J., \& Altaf, U. (2015). I'm loving it but hating US. British Food Journal.

Kashif, M., Rehman, M. A., \& Pileliene, L. (2016). Customer perceived service quality and loyalty in Islamic banks. The TQM Journal.

Khan, A. S., \& Rasheed, F. (2015). Human resource management practices and project success, a moderating role of Islamic Work Ethics in Pakistani project-based organizations. International Journal of Project Management, 33(2), 435-445. 
Kraft, M. E., \& Furlong, S. R. (2019). Public policy: Politics, analysis, and alternatives. Cq Press. Lehtonen, P., \& Martinsuo, M. (2006). Three ways to fail in project management and the role of project management methodology. Project Perspectives, 28(1), 6-11.

Lundin, R. A., \&Söderholm, A. (1995).A theory of the temporary organization.Scandinavian Journal of management, 11(4), 437-455.

Luu, T. V., Kim, S. Y., Cao, H. L., \& Park, Y. M. (2008). Performance measurement of construction firms in developing countries. Construction Management and Economics, 26(4), 373-386.

Magassouba, S. M., \& Alkhlaifat, B. (2018). Factors Contributing To Project Success among Organizations in Guinea. Saudi J. Bus. Manag. Stud, 3, 617-622.

Magassouba, S. M., Tambi, A. M. B. A., Alkhlaifat, B., \& Abdullah, A. A. (2019). Influence of Stakeholders Involvement on Development Project Performance in Guinea. International Journal of Academic Research in Business and Social Sciences, 9(1), 1111-1120.

Mathiaszyk, L., Volkmann, C., \& Read, S. (2019). Effectual Project Management: Thinking Like an Expert Entrepreneur2.

Manochehri, N., Al-Esmail, R., \&Ashrafi, R. (2012). Examining the impact of information and communication technologies (ICT) on enterprise practices: A preliminary perspective from Qatar. The Electronic Journal of Information Systems in Developing Countries, 51.

McGrew, J. F., \& Bilotta, J. G. (2000). The effectiveness of risk management: measuring what didn't happen. Management Decision, 38(4), 293-301.

Mentis, M. (2014). Science writing in the real world. Forest Ecosystems, 1(1), 1-8.

Ministry of health (MOH), Jordan (2017), Available from: http://www.moh.gov.jo/Pages/viewpage.aspx?pagelD=250

Mir, F. A., \& Pinnington, A. H. (2014). Exploring the value of project management: linking project management performance and project success. International journal of project management, 32(2), 202-217.

Mohamad, M., Afthanorhan, A., Awang, Z., Mohammad, M. (2019), Comparison between CBSEM and PLS-SEM: Testing and confirming the Maqasid syariah quality of life measurement model. The Journal of Social Sciences Research, 5(3), 608-614.

Müller, R., \& Turner, R. (2007). The influence of project managers on project success criteria and project success by type of project. European management journal, 25(4), 298-309.

Müller, R., \& Turner, R. (2010). Leadership competency profiles of successful project managers. International Journal of Project Management, 28(5), 437-448.

Munns, A. K., \& Bjeirmi, B. F. (1996). The role of project management in achieving project success. International journal of project management, 14(2), 81-87.

Muriithi, P., Horner, D., \& Pemberton, L. (2016). Factors contributing to adoption and use of information and communication technologies within research collaborations in Kenya. Information Technology for Development, 22(sup1), 84-100.

Naeem, S., Khanzada, B., Mubashir, T., \&Sohail, H. (2018). Impact of Project Planning on Project Success with Mediating Role of Risk Management and Moderating Role of Organizational Culture, 9(1), 88-98.

Noor, N. M., Aziz, A. A., Mostapa, M. R., \& Awang, Z. (2015). Validation of the Malay version of the Inventory of Functional Status after Childbirth questionnaire. BioMed research international, 2015.

Odeh, A. M., \& Battaineh, H. T. (2002). Causes of construction delay: traditional contracts. International journal of project management, 20(1), 67-73. 
Packendorff, J. (1995). Inquiring into the temporary organization: new directions for project management research.Scandinavian journal of management, 11(4), 319-333.

Papaioannou, A., Parkinson, W., Cook, R., Ferko, N., Coker, E., \& Adachi, J. D. (2004). Prediction of falls using a risk assessment tool in the acute care setting. $B M C$ medicine, 2(1), 1.

Porter, T. M. (1996). Trust in numbers: The pursuit of objectivity in science and public life. Princeton University Press.

Qureshi, T. M., Warraich, A. S., \& Hijazi, S. T. (2009). Significance of project management performance assessment (PMPA) model. International Journal of Project Management, 27(4), 378-388.

Rabechini Junior, R., \& Monteiro de Carvalho, M. (2013). Understanding the impact of project risk management on project performance: An empirical study. Journal of technology management \& innovation, 8, 6-6.

Raheem, O. A., Olateju, O. I., \& Hammed, O. G. (2012).Effect of Project Management on Project Success.Australian Journal of Business and Management Research, 2(3), 1.

Rahrovani, Y., Chan, Y. E., \& Pinsonneault, A. (2014). Determinants of IS planning comprehensiveness. Communications of the Association for Information Systems, 34(1), 59.

Ramirez-Cortés, F., Holm-Nielsen, N. B., Ishizawa, O. A., \& Lam, J. C. (2012). The missing link: Disaster risk information for urban development policies and programs. In Sixth Urban Research and Knowledge Symposium, Rethinking Cities: Framing the Future.

Samarah, A., \& Bekr, G. A. (2016). Causes and effects of delay in public construction projects in Jordan. American Journal of Engineering Research, 5(5), 87-94.

Shenhar, A. J., \& Dvir, D. (2007). Reinventing project management: the diamond approach to successful growth and innovation. Harvard Business Review Press.

Shengli, Z., Wenbin, W., Weining, L., \&Meili, L. (2008). Discussion on risk management of subway projects. Urban Rapid Rail Transit, 21(1), 56-60.

Sanvido, V., Grobler, F., Parfitt, K., Guvenis, M. \& Coyle, M. (1992) Critical success factors for construction projects, Journal of Construction Engineering and Management 118(1): 94-111.

Serrador, P., \& Turner, R. (2015). The relationship between project success and project efficiency. Project Management Journal, 46(1), 30-39.

Slevin, D. P., \& Pinto, J. K. (1986). The project implementation profile.Project Management Journal, 17(4), 57- 70.

Sweis, G., Sweis, R., Hammad, A. A., \&Shboul, A. (2008). Delays in construction projects: The case of Jordan. International Journal of Project Management, 26(6), 665-674.

Sweis, R. (2015). An investigation of failure in information systems projects: The case of Jordan. Journal of Management Research, 7(1), 173-185.

Sweis, R. J., Bisharat, S. M., Bisharat, L., \&Sweis, G. (2014). Factors affecting contractor performance on public construction projects. Life Science Journal, 11(4s), 28-39.

Turner, J. R. (2006). Towards a theory of project management: The nature of the project governance and project management.

Wu, Z., Nisar, T., Kapletia, D., \& Prabhakar, G. (2017). Risk factors for project success in the Chinese construction industry. Journal of Manufacturing Technology Management, 28(7), 850-866. 
Yun, S., Choi, J., de Oliveira, D. P., \& Mulva, S. P. (2016). Development of performance metrics for phase-based capital project benchmarking. International Journal of Project Management, 34(3), 389-402.

Yusof, Y., Awang, Z., Jusoff, K., Ibrahim, Y. (2017), The influence of green practices by nongreen hotels on customer satisfaction and loyalty in hotel and tourism industry. International Journal of Green Economics, 11(1), 1-14.

Zhang, H. (2007). A redefinition of the project risk process: Using vulnerability to open up the event-consequence link. International journal of project management, 25(7), 694701.

Zwikael, O., \&Ahn, M. (2011). The effectiveness of risk management: an analysis of project risk planning across industries and countries. Risk Analysis: An International Journal, 31(1), 25-37.

Zwikael, O., \& Smyrk, J. (2012). A general framework for gauging the performance of initiatives to enhance organizational value. British Journal of Management, 23, S6-S22.

Zwikael, O., Pathak, R. D., Singh, G., \& Ahmed, S. (2014). The moderating effect of risk on the relationship between planning and success. International Journal of Project Management, 32(3), 435-441. 